\title{
REGIONAL OBSERVATORIES OF DEVELOPMENT POLICY AS A TOOL FOR MONITORING THE EFFICIENCY OF THE COHESION POLICY
}

\author{
WOJCIECH JARCZEWSKI \\ Institute of Urban Development \\ Cieszyńska 2, 30-015 Kraków \\ e-mail: jarczewski@poczta.fm
}

\begin{abstract}
In the ten new EU-Member States from the Central Europe, similarly to the whole community, the regions establish their Regional Operating Programmes in direct co-operation with the European Commission and thus they can significantly influence the directions of regional development. Responsible programming requires solid foundations for the purpose of evaluation of the projects. Presently, the regions of the new member states suffer from a serious shortage of instruments required for such evaluation. The Regional Development Policy Observatory network could play the role of the supporters of regional authorities in the respective countries. Such Observatories, allowing to monitor the influence of the aid resources on the regional development could be organized in each region, in accordance with the following assumptions:

1) Monitoring and evaluation of the development policy are continuous tasks.

2) The indicators used in monitoring activities and partial evaluations of the influence of the public intervention instruments create a complete system and integrate the existing measurement and evaluation tools applied by regional authorities.

3) Professional and continued operations of the Observatories require institutional approach: in the long term, monitoring institutions should be established, and, with time, they would be transformed into a network of regional think-tanks.

4) The results of analyses and evaluations resulting from the Observatory operation should be made publicly available. It is essential for the form of result presentation, at least in part, to be easily understood by local communities.

5) The development policy evaluations and the consequential revision proposals regarding the regional government interventions should be the objects of regular public debates. A starting point for the preparation of a uniform methodology for the Regional Development Policy Observatories is the assumption that the methodology should be based on three modules:
\end{abstract}


Module I - monitoring of the economic development processes and regional residents' quality of life. As part of this module, wide-scale analyses of the diversity of social and economic development and the rate of change would be conducted in each region.

Module II - measurement and evaluation of public interventions, especially of the absorptions of aid funds and their direct effects. As part of this module, information on possibly all interventions implemented in the regions, with the use of aid funds, would be collected.

Module III - presentation of a general evaluation of the regional policy and the evaluation of particular instruments of such policies, and, in particular, description of the influence of the EU programmes on the regional and local development. Module III will be used for the implementation of the basic purpose of the establishment of the Observatories and it will be based on the results of Modules I and II.

Key word: regional development policy, regional development indicators, monitoring, Poland

\section{INTRODUCTION}

After Poland joined the European Union, the Polish regional governments obtained considerable possibilities of stimulating social, economic and spatial development of regions. In the current programming period of 2007-2013, the scale of financial possibilities, together with the responsibility for selecting proper development directions, has even increased, mainly owing to the Regional Operating Programmes. In addition, it is in the regions where specific projects are implemented under the Programmes or initiatives managed from the national level, while their effects also concern local and regional structures.

Monitoring of the implementation of such Programmes and projects belonging to them, followed by the evaluation of how they influence the development, should be conducted primarily at the regional level. Such, let's say Regional Development Policy Observatories (ROPR's), should operate in each region (or 16 voivodships in Poland). To generalize and compare the results and develop synthetic studies for the whole country, it will be indispensable to establish a uniform methodology (including indicators and measures) that would be a basis for such Observatories to operate in particular regions.

The basic goal of the development of Regional Development Policy Observatories by the Marshal's Offices (Marshal is the head of the regional management board in Poland) include the following: creation of the instruments (or information gathering and processing) allowing for the evaluation of the rate and scale of the attainment of the development objectives in particular regions as a result of the implementation of the programmes and projects carried out with the use of EU aid funds ${ }^{1}$.

Such a definition of the goal means that ROPR's should serve mainly the regional governments, as well as constitute the instruments of the central government's regional policy implementation. The results of the studies conducted by the Observa-

\footnotetext{
${ }^{1}$ Regional and National Operating Programmes, Community Initiatives, Cohesion Fund etc.
} 
tories may also be used in various types of statistics and generalizations, including the comparisons to be developed on the national level (e.g. by the Ministry of Regional Development). Some of the results should be of interest to the county and municipal levels of administration as well. Regional communities and various types of experts involved in the regional development will also become important recipients of such studies.

The attainment of the goal specified in that way will require the creation of the tool in the form of the Regional Development Policy Observatories, for which the following assumptions should be accepted:

- An Observatory will be created in each Polish region. The methodology of information gathering, processing and presentation will be partly uniform and standardized for all the ROPR's. As a result, it will be possible to synthesize some of the results of the works and compare them across the country.

- The analyses and studies will be conducted professionally and systematically during the pre-planned time frames. With time, the ROPR's will become partly independent of the regional authorities and operate as regional "think tanks." The creation of the Observatories will be preceded by the planning of methods, scale and types of necessary works, as well as of technical tools.

- The research conducted by the Observatories will be integrated by monitoring of the attainment of the objectives of all the Regional Strategic Programmes (including e.g. the Regional Development Strategies, Regional Innovation Strategies, or Regional Operating Programmes).

- Research results will be made available to local communities and interested experts, although they will be prepared mainly for the needs of decision makers and used in the local and regional development process programming.

\section{ROPR MODULES}

The Regional Development Policy Observatories should be based on the analyses conducted within three modules:

- Module I: the evaluation of the use of aid funds in the region, including identification of the direct effects resulting from the application of such resources.

- Module II: monitoring of social, economic and spatial regional development processes in the region, in the context of the developmental goals, with identification of barriers. Modules I and II should operate concurrently and independently of each other.

- Module III: the evaluation of the influence of the interventions, implemented with the use of aid funds, on regional development. Under that Module, the main goal of ROPR's would be attained, that is search for interrelationships between the regional development and the interventions being implemented. Under Module III, the results of the works conducted within Modules I and II would be integrated (Figure 1). 


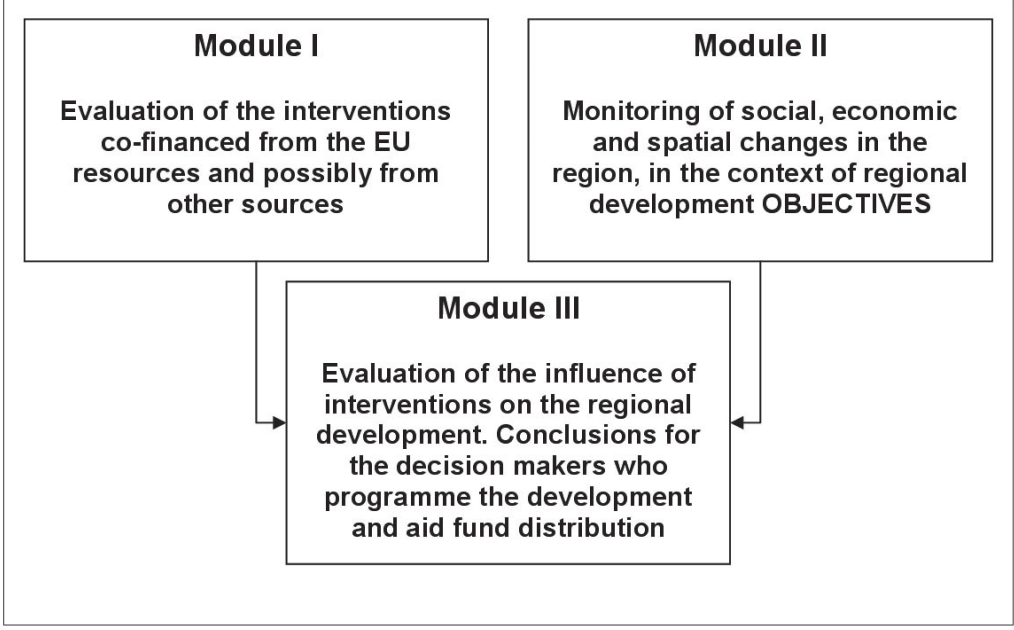

Figure 1. Regional Development Policy Observatories Module Diagram

\section{JUSTIFICATION OF THE NEED TO ESTABLISH ROPR'S}

The need to build such a costly and complex institution network as the ROPR's has been determined to a large degree by the results of previous attempts at the evaluation of the influence of EU aid funds on regional development. Even presently, we have access to various studies which use fairly advance statistical models to demonstrate the significance of EU aid funds spent by the end of 2008 from the pool prepared for the first programming period of 2004-06. It is popular to use for both projections and monitoring of such models as HERMIN (Bradley et al. 2006; Zaleski et al. 2007) or MaMoR2 (Kaczor and Socha 2008). Some of research teams prepare their own model conceptions, e.g. the Institute of Structural Research proposed the EUImpactMOD model (Bukowski et al. 2008).

All those models are, however, based mainly on the information originating from the Regional Data Bank of the Central Office of Statistics (GUS), also using the macro-economic assumptions that may not describe reality correctly on the regional scale. The evaluation of the influence of aid funds on the labour market may not be reduced, however, to a comparison of the number of projects and the allocated amounts to the changes in the unemployment rates, claiming that such projects have caused the related positive changes. Such evaluations are very difficult to verify, and the results depend to a large degree on the assumptions. It is not possible to identify such issues as the following from that perspective, e.g.:

- Where were the resources allocated (in the regional capital city or rather in peripheral counties of the region)?

- Did the project structure correspond to the local needs?

- Were the particular projects under various programmes or priorities complementary, or were they carried out independently?

- What was the quality of the projects carried out with the use of aid funds? 
On the other hand, a number of evaluation studies have been carried out with respect to particular projects, priorities and programmes where people try to find answers to the quality questions asked above. When evaluating particular projects:

- We lose a chance to evaluate the influence of all the interventions on transformations.

- Evaluations are usually made soon after the project completion, or even during the project continuation, without considering long-term project effects.

The attempts at the integration of the two approaches within single studies have not brought satisfactory results: that issue is too complex and it requires too many detailed analyses. The integration of the two types of evaluation, in the context of social, economic and spatial transformations in the region, would be better attained by the ROPR's operating long-term in a stable manner.

What is an especially difficult problem is the inadequate quantity of data concerning social, economic and spatial development. Despite general digitalization, the quantities of data available to analysts intending to do research on the inter-regional diversity has not changed since the 1980's, and may be even lower in some areas.

Presently, there is a number of large databases which allow to follow various social and economic transformations, using advanced software. The basic problem is, however, the availability of information, as well as the diversity of the systems in which the data are stored and processed. One of the ROPR's tasks will be to identify the data sources and simplify data acquisition directly from the sources, plus data processing.

\section{EXPANSION OF OBSERVATORIES' OPERATING SCALE: STAGING}

When commencing the construction of a Regional Development Policy Observatory, we can assume that it should be possible in the future to analyse the influence of all public interventions (financed from the EU resources, municipal, county and regional budgets, as well as by the central government) on the regional development. It seems, however, that it is possible to test such a tool on the interventions that have been co-financed by the EU, owing to a fairly high transparency of the projects and programmes and the small number of managing and implementing organizations.

The present study supports the establishment of more and more discussed and needed Regional Development Policy Observatories. Due to the limited size of this study, we have presented only a sketch of the ROPR conception. Before the conception implementation stage, further works will be required to allow for developing the system's details. It also seems practical to test the ROPR tool in one or two regions and expand the system to all regions after conclusions have been voiced. 


\section{ROPR INSTITUTIONALIZATION}

Effective implementation of the goal for which the Regional Development Policy Observatories will be established will require conducting regular and long-term analytical and evaluation works. Research stability and continuity will require certain institutionalization of each ROPR. At the present stage, it is hard to decide about the target or the most desired organizational form. However, even now, certain premises can be made and taken into account in the institutionalization process. They are related to the following:

- Need to coordinate the ROPR's on the national level.

- Work quality.

- Research and evaluation integration on the regional level.

- Independence of temporary or political needs.

Properly designed and financed Regional Development Policy Observatories can become, within several years, a network of regional think tanks, or the organizations providing a strong intellectual support for regional, as well as county and municipal governments. With time, the ROPR's will become personnel sources for local and central government administration in each region.

\section{NATIONAL COORDINATION REOUIREMENT}

The requirement of applying a certain minimum level of uniform data gathering, processing and visualization methodology will allow for the information generalization and preparation of nation-wide analyses. It seems that, at the present stage, ROPR development coordination and methodology preparation (to be uniform for all the Polish regions) can be assumed by the Ministry of Regional Development (MRR). The ministerial coordination would also allow for obtaining certain guarantees that the Observatories would become operational in all the regions.

The system can be voluntary for the regions, although joining it would be associated with the possibility of using incentives in the form of:

- Free training for the ROPR workers,

- Free provision of methodology and possibly software,

- Possibility of applying for additional resources that would cover, at least partly, the ROPR's operating costs in the regions,

- Access to the most recent and upgraded ministerial databases.

An ROPR Forum should be created in the Ministry. That would be a platform for the exchange of experience, knowledge and good practice between the Observatories in particular regions. As part of the Forum, common research methodology would be discussed, developed and revised.

The Regional Investor Service Centres could provide inspiration for the organization of the ROPR network. 


\section{REGIONAL INVESTOR SERVICE CENTRES AS AN EXAMPLE OF NATIONAL COORDINATED NETWORK OF LOCAL-GOVERNMENT ORGANIZATIONS}

One of the examples providing a model of ROPR coordination system are the successful Regional Investor Service Centres (COI) that support pro-investment activities and are conducted by the Polish Information and Foreign Investment Agency (PAIiIZ).

The COI Centres (www.paiz.gov.pl) were established in close co-operation with the Regional Marshals who are responsible for the promotion of regions under statutes, and the Centres operate mainly within the Marshal Office's and Regional Development Agencies' structures (Figure 2). The COI personnel operate in accordance with the standards determined by PAIiIZ. The workers were trained by the Agencies and are provided with regular substantive assistance by the Agencies. Each Centre covers one region where it has its office, becoming a source of current data on the regional economy. The Centres also have contact databases with local governments and business-support organizations operating in the region. The main goal of COI operation is to ensure comprehensive investor services on the regional level. The Centres co-operate with PAIiIZ when handling capital-investment projects and provide their investor services independently when the investors contact them directly. The COI's co-operate closely with PAIiIZ by exchange of information (quarterly reports drafted by the Investor Service Centre officers show the Centre's activities in the context of applications made by the potential investors).

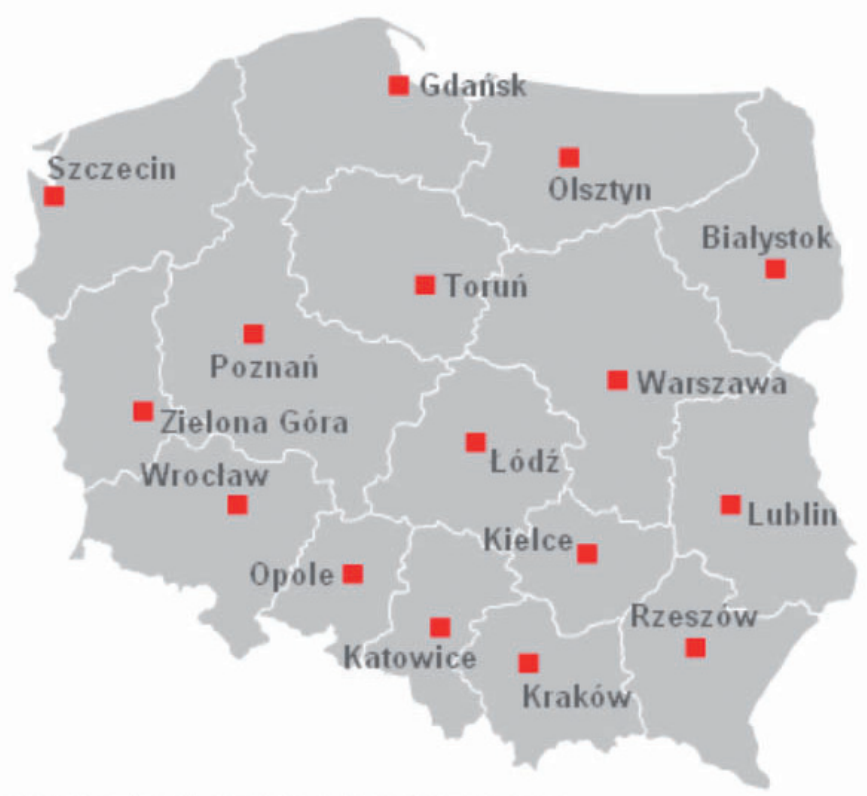

Figure 2. Distribution of regional investor service centres in Poland Source: <www.paiz.gov.pl> 


\section{WORK QUALITY}

An essential factor that influences the ROPR's performance will be the personnel quality. To maintain a high professional level of the personnel and proper rate of works, it will be necessary to ensure suitable resources. As a result, some of the studies prepared by the ROPR's may be more expensive than the analyses which are prepared by various kinds of experts (under low-taxed project contracts) or some consulting companies. In the light of the public procurement law, that problem may constitute grounds for accusation of the regional authorities of mismanagement. When choosing the legal form of ROPR's, it will be necessary to take into account that restriction and the awareness that high quality of works will require adequately large and stable expenditures. In exchange, we will obtain the continuity of research and strengthening of the so-called institutional memory.

\section{INTEGRATION OF RESEARCH AND EVALUATION WORKS ON THE REGIONAL LEVEL}

In addition to the execution of research and evaluation works, ROPR's should also gather as many as possible studies and social, economic and spatial works developed for the region by other entities (e.g. universities, research institutes, or consulting companies). The analysis of the regional studies will increase the knowledge resources. Such studies would also present conceptions of study order formulation for the Marshall Offices to allow for the use of works in the ROPR's works.

It is hard to resolve at the present stage how many studies would be conducted by ROPR's workers and what part of such studies would be ordered from experts and independent organizations. Undoubtedly, there are serious premises for some analyses to be ordered from independent teams. In such cases, the ROPR's would be involved only in coordination and quality and methodology supervision of such studies, plus gathering of possibly all source data. The operating system of the Health Technology Assessment Agency (AOTM) attached to the Polish Ministry of Health may be an inspiration of the introduction of such a system.

\section{THE HEALTH TECHNOLOGY ASSESSMENT AGENCY AS AN EXAMPLE OF THE RESEARCH PERFORMING AND SUPERVISING ORGANIZATION}

The Health Technology Assessment Agency was established in 2006 by the Regulation of the Minister of Health (www.aotm.gov.pl).

It is a government agency, with opinion-making and advisory functions. It is mainly involved in the issuance of recommendations for medical technologies by order of the Ministry of Health and the National Health Fund.

The main AOTM body is the Consulting Council. The Council, composed presently of eleven members, issues recommendations on whether and to what degree and in what form medical technologies should be financed from public resources. The final decisions on the technology implementation are made, however, by Ministry of Health. 
The Consulting Council issues its decisions based on meta-analyses in which the experts provide thorough evaluations, based on international literature and research, whether given medical technologies (medicines) are primarily safe and effective for the patients and whether the application costs are commensurate with therapeutic effects. Some of meta-analyses, being the basis of the Consulting Council's decisions, are prepared by the AOTM workers, although the majority are ordered by independent consulting companies from the heath technology assessment sector, while AOTM only verifies their works.

\section{INDEPENDENCE}

The implementation of programmes and projects with the use of aid funds causes various types of positive, neutral and, in some cases most certainly, negative effects. The ROPR workers should be assured at least partial independence. The judgments and opinions formulated by them should be free of pressure and result directly from their analyses.

\section{MODULE I: EVALUATION OF THE INTERVENTIONS CO-FINANCED FROM THE EU RESOURCES (AND POSSIBLY OTHER SOURCES), INCLUDING IDENTIFICATION OF DIRECT EFFECTS RESULTING FROM THE USE OF SUCH RESOURCES}

Evaluation is understood here as the application of various research methods to data gathering, analysis, interpretation, evaluation and information dissemination on the quality and value of interventions (projects and programmes), (Olejniczak 2008). co-financed from the EU resources. The ROPR's tasks under Module I (evaluation of the interventions co-financed from the EU resources):

a) certification of all research on the evaluation of the interventions co-financed from the EU resources conducted in the region:

- Working out and preservation of comprehensive and cohesive methodologies and structures of evaluation studies.

- Source data gathering; evaluations will be conducted based on such data (e.g. results of surveys in a non-aggregated database format, non-aggregated indicators etc.).

b) Carrying out selected evaluations, especially those that are essential for regional authorities.

c) Collection of data on all the interventions co-financed from the EU resources conducted in the region, including information on direct effects of particular projects (e.g. success indicators).

d) Rejected Project Database.

It is necessary to mention that information on all programs and projects co-financed from the EU resources conducted in the region should be collected in this 
Module. The implementing organizations and supervising government Ministries should provide ROPR's with the data of each project which was granted resources and designed for implementation at least partially in the given region.

In the ROPR's, the project data will be processed mainly after the data are fed from central databases, e.g. the National Information System SIMIK 07-13. We should expect that such systems will be adequately efficient in the near future to serve the ROPR's. Such an approach will allow to relieve ROPR's and will contribute to the reduction of their operating costs.

Information on the projects under implementation should be gathered and comprehensively processed at least once a year, except for some information which has to be processed on a semi-annual or even quarterly basis.

\section{PROGRAMME EVALUATION}

Evaluation of the types: ex-ante, ex-post and on-going in respect of particular programmes and their parts. Under that activity, the evaluation actions that are performed and ordered by the Marshal Offices, in accordance with the formal requirements of particular programmes, would be integrated. The implementation status of projects and activities would be evaluated, together with direct effects resulting from the use of respective resources, main product indicators and, in some cases, also the success indicators. The data collected under that system would become the grounds for conducting comparative analyses in respect of the resource absorption (the number and value of approved projects) in comparison to other regions in Poland and EU.

As part of that activity, also the opinions on the whole process of project application preparation, evaluation and implementation will be collected. A Good Practice List will be kept, with the presentation of the known barriers and limitations, as well as the methods of overcoming them. Owing to the implementation of proper information storage, analysis and dissemination procedures, it will be possible to create a kind of "institutional memory" that will be fairly resistant to unavoidable turnover of experienced workers.

\section{SUBSTANTIVE AND SPATIAL PROJECT ANALYSIS}

That will be an indication of the scale of interventions co-financed from the UE resources and designed for particular sectors of social, economic and spatial development. The thematic or substantive approach will allow for indication of the directions of allocations, without any limitations resulting from the structure of particular programmes. That goal will be achieved by assignment of a proper intervention category to each project. After such classification, it will be possible to conduct project analysis under particular intervention categories and their groups. Additionally, information will be gathered on each project in respect of its spatial location. The best would be to assign projects to particular municipalities. Infrastructural projects, and in particular the linear capital investments, should also be marked on maps and analyzed in the spatial context. 
In Table 1, we have proposed a minimum scope of information that should be collected for each project implemented in the given region.

Table 1. Proposed range of collected data on each regionally implemented project

\begin{tabular}{|c|c|c|c|c|c|c|c|c|c|c|c|c|}
\hline 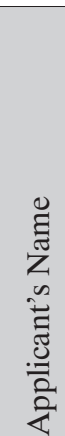 & 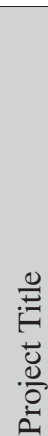 & 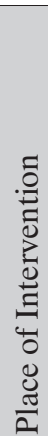 & 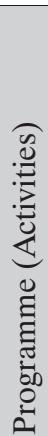 & 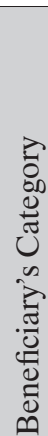 & 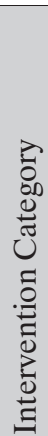 & 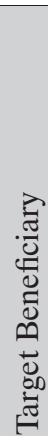 & $\begin{array}{l}\stackrel{0}{\pi} \\
\frac{\pi}{\nu} \\
\frac{0}{0} \\
\frac{0}{0} \\
0 \\
\frac{\pi}{0} \\
0 \\
0\end{array}$ & 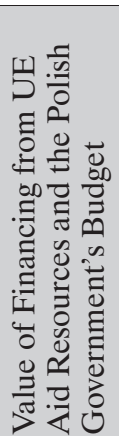 & 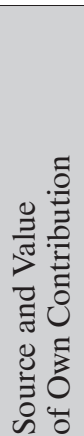 & 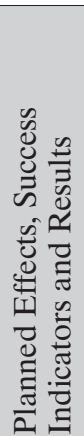 & 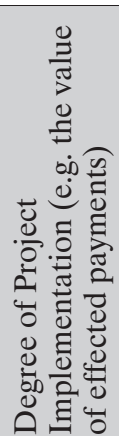 & 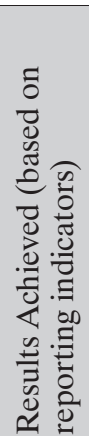 \\
\hline & & & & & & & & & & & & \\
\hline
\end{tabular}

Source: own studies.

\section{REJECTED PROJECT DATABASE}

That concerns collection and processing of information on the project applications that have been submitted but rejected for formal or substantive reasons, or otherwise have not been co-financed due to inadequate quantity of resources. The analysis of the activities of particular groups of potential beneficiaries and the priorities and activities that have been particularly attractive will allow us to indicate the areas and problems in which there is a larger need of aid funds than in other sectors.

At the same time, we would create a certain "pro-development project database," or the Rejected Project List, specifying the projects which could be reconsidered under later requests or other programmes. The organizations that invested in the preparation of their rejected projects applications would have another chance, after revision, for supplementing or even reworking of their projects to obtain resources from other sources. In that way, owing to co-operation with potential beneficiaries on specific proposals, it will be possible to increase the quality of applications in the given region in the long run.

\section{MODULE II: MONITORING OF SOCIAL, ECONOMIC AND SPATIAL TRANSFORMATIONS IN THE REGION IN THE CONTEXT OF REGIONAL DEVELOPIENT OBJECTIVES}

Monitoring of the transformations occurring in the region, understood as collection and analysis of the data on social, economic and spatial issues to create the grounds for preparation of the evaluation of the compliance of the observed processes with 
strategic objectives. The region's strategic development objectives are contained in the local strategic documents. The reference point for monitoring is the diagnosis to be prepared for the starting point and repeated in assumed fixed time periods. The analysis of the tendencies, trends and transformations occurring between such diagnoses consists in monitoring. The indicators and measures for identification of development processes are recorded in the regions' programme documents. Quantitative and qualitative indicators would be subjected to observation, as well as certain thematic issues.

The ROPR's tasks under Module II include monitoring of social, economic and spatial transformations in the region, in the context of the regional development OBJECTIVES which will allow as follows:

a) To prepare regular diagnoses of the region's condition, allowing to evaluate the range of achieving the development objectives, including:

- Evaluation of the region's position among Polish and EU regions.

- Identification of thematic areas issues for which interventions are particularly required.

- Identification of new development possibilities and methods of achieving them.

b) Preparation of extensive reports on the selected issues that are especially important in the given time and related to regional development.

c) Preparation of regional development projections and options for the needs of local governments which would allow to connect strongly the decision-making processes with specific research results.

d) Preparation and drafting of materials constituting reference points to which analyses of interrelationships between the resources spent and the results obtained in the whole region would be conducted under Module III.

\section{GENERALIZATION LEVELS AND RESEARCH FREQUENCY}

Undoubtedly, three reference levels are required: counties (powiaty), municipalities (gminy), and, in case of linear and some point projects, particular locations.

It seems to us that the most proper level for the analysis of the internal differences are the Polish counties. In case of some phenomena, it will be necessary to use a more detailed scope down to the municipality level. Such spatial phenomena as e.g. the development of technical infrastructure (roads, water pipelines, sewage systems, river management etc.) should be analyzed in the space with the application of proper software in reference to e.g. the development density or traffic intensity. The use of advanced GIS-type software will also allow to analyze certain phenomena taking into account the data assigned to address points.

It is also worth considering to conduct a multi-criteria municipality typology, followed by providing detailed analyses of the selected municipalities that are recognized to be characteristic for a given group.

It seems that, at least every four years, a wider and comprehensive analysis should be conducted. The majority of indicators would be monitored once a year, although, 
in some special cases, it would be possible to review regional transformations and processes even on a quarterly basis.

\section{REGIONAL DEVELOPMENT INDICATORS}

The performance of the main ROPR's task, which is monitoring of the attainment of regional development policy objectives in the context of the use of EU aid resources, will require each time to adjust the list of indicators to the requirements of the regional strategic documents. However, we can identify about seven groups of issues which should be monitored in all regions:

- Social cohesion of the region (including unemployment, exclusion, crime rate, social welfare, education level, housing conditions, migration balance, medical care etc.).

- Economic cohesion of the region (GNP per capita, foreign capital investments, export, investment attitude, clusters and technological parks, business activities of the residents etc.).

- Spatial cohesion: infrastructure for the regional development (e.g. road infrastructure, airports, motorways, public transport, including modernized railway lines, access to broad-band Internet).

- Significance of large cities and metropolitan areas (e.g. the number of international corporations' headquarters, modern office space availability, international connections, number of international congresses, number of people using integrated metropolitan transportation).

- Environmental protection (e.g. water and air pollution, waste treatment facility quality and quantity, rate of spreading development to suburbs, protected areas).

- Cultural heritage (e.g. the scale of urban degradation and revitalization, expenditures on landmark preservation works, changes in the number of landmarks and protected areas).

- Modern public management (e.g. election turnout, range of public on-line services, number of effective sentences in corruption cases).

\section{SOURCES OF DATA AND MODEL ANALYSES}

Even the best developed model will not be able to generate valuable analysis at output, without good data at input, not to mention reliable projections. Analysts come across that problem for many years when trying to evaluate cause-effect relationships between various types of events and socio-economic processes that occur in Polish towns and regions. The analytical possibilities based on the BDR GUS data have been basically used up and they do not satisfy many monitoring or regional process evaluation requirements. There is an urgent need of identification and organized use of other databases being independent of those provided by GUS.

The agencies and offices operating in the region possess and constantly update huge quantities of data. Enclosure 1 to this study specifies a whole list of databases that exist in particular organizations, and that list is not complete but it is only an example of the scale of the situation. In the future, as part of the INSPIRE directive being implemented, the access to some of those databases will be ordered and 
facilitated. In the next years to come, the regions interested in social, economic and spatial process monitoring will have to develop their own systems of data acquisition and processing, directly from the data-gathering institutions: Treasury Offices, County Labour Offices, Police etc.

\section{MODULE III: EVALUATION OF THE INFLUENCE OF INTERVENTIONS ACCOMPLISHED WITH THE USE OF AID FUNDS ON THE REGION'S DEVELOPMENT}

Under that Module, the main ROPR objective would be attained, that is search for interrelationships between the region's development in accordance with the designated objectives and implemented interventions co-financed from the EU resources. Under Module III, the results of the works conducted under Modules I and II will be integrated.

The first programming period whose performance was basically completed in accordance with the principle of $\mathrm{n}+2$ in 2008 matched a quick economic development of Poland. The main task of the analysts who were trying to evaluate the influence of the completed projects on social and economic development (e.g. reduction of unemployment) in recent years was to look for answers to the question what part of that success could be assigned to the projects co-financed from the EU resources. The assumed success and influence indicators were mostly achieved and even exceeded. Co-occurrence of such two processes (allocation of resources and quick development of Poland) was recognized to be a proof of the effectiveness of current policy. As it was indicated by the example of the Małopolska region, drawing such far-reaching conclusions, based mainly on the GUS data and without observing proper time perspective, seemed to be rather premature and often unjustified for all regions.

The Regional Development Policy Observatories, using good data describing the phenomena and social, economic and spatial transformations occurring in the region, as well as possessing knowledge on the implemented and completed projects co-financed from the EU resources, will attempt at interrelating both types of occurrences under Module III. Such an evaluation will be carried out by analysis and synthesis (Prawelska-Skrzypek and Domański 2006).

\section{SPATIAL ANALYSES, WITH THE USE OF GIS-TYPE SOFTWARE}

Especially interesting, original and very precise information will be available by imposing the layers that demonstrate social or economic transformations on the ones which show the allocation of resources that were available under particular interventions and in the completed infrastructural projects. By comparing the trans-formations on the areas that were covered by such interventions to the processes occurring on similar areas, but bereaved of such opportunities, one will be able to try to evaluate the actual influence of allocations. That approach will allow to apply a certain municipality typology and analyze the processes that occur on various types of areas. 


\section{QUALITATIVE ANALYSES}

Once we have a reliable substantive basis in the form of credible and current "hard" statistics, we will be able to use the so-called expert opinions. The experts will apply e.g. the Delphi method to evaluate the course of implementation of the projects co-financed from the EU resources. Theoreticians, scholars and practitioners (workers from the local governments, government agencies and other organizations participating in the resource management) will be invited to participate in evaluation meetings. Equally important will be the voice of local communities whose members will be able to participate in various discussions and internet forums. It will also be necessary to carry out surveys among the region's residents.

\section{INTERRELATIONSHIP ANALYSES}

That concerns the analyses using various types of statistical models being the basis of identification of various types of interrelationships between the fund absorption under particular intervention categories and the data demonstrating social, economic and spatial transformations.

\section{SYNTHETIC EVALUATION}

As part of synthetic analysis and using analytical evaluations, analysts will indicate the degree of attainment of the objective determined for the region's development, owing to the utilization of aid means. The following will be shown:

- The areas of social and economic life whose development was affected by project completion.

- The areas that gained substantively owing to the acquisition of aid resources (in comparison to other comparable areas).

- The weaknesses related to the implementation of particular programmes and projects, as well as the areas which, despite serious needs, were unable to apply for proper financing.

- Evaluation of the effect durability, compliance of the development with the objectives of the regional development policy, complementary and complexity aspects of the implemented interventions.

- Recommendations for the politicians who programme subsequent stages of regional development.

\section{CONCLUSIONS}

a) Objectives of the establishment of the Regional Development Policy Observatories by the Marshal Offices: indication of how the regionally established development objectives have been implemented as a result of the introduction of the programmes and projects co-financed from the EU aid funds. The Observatories will monitor the objective attainment, as specified in all regional programme documents and in all the projects co-financed from the EU funds (Operating Programmes, Community Initiatives, Cohesion Fund etc.). 
b) ROPR's will be gradually established in all the Polish regions and they will become with time a network of independent agencies, or regional think tanks that will use a common research methodology in part. The Observatory work coordination will be assigned to the Ministry of Regional Development, although Regional Marshal Offices should be the founding authorities for the Observatories. Some of the research should be individual and directed to the needs of the respective regions, while part should be common for all the regions.

c) The Observatories will carry out research works under three Modules: Module I - measurement and evaluation of the use of aid funds in the region; Module II - monitoring of the directions and rate of regional development. Those two modules should operate concurrently. Module III will integrate the results of completed research and answer the question what are the interrelationships between the aid fund absorption and the development processes.

d) The need to establish the ROPR's results from the imperfection of the existing statistical models that evaluate the influence interventions on regional development, associated e.g. with the inadequate lists of data collected by GUS. At the same time, evaluations of particular programmes are unable to cover completely the interventions conducted in regions. In the future, monitoring of all public interventions will be conducted by the Observatories.

e) Conducting objective and solid analyses requires certain separation of the Observatories from the Marshal Office structures, with assurance of stable financial resources and employment of high-class experts.

f) The Observatories should integrate possibly all research works relating to regional development and evaluation on the regional level. A considerable portion of such tasks can be performed by independent research teams, while the ROPR's should care for unification of methodologies and collection of source data.

g) The Observatories will gather data on all the projects implemented in the given region, with the application of the EU resources. Such data will be received by the Observatories from such central databases as e.g. the National Information System SIMIK 07-13.

h) With reference to all programmes and projects, the following will be carried out:

- Certification of all evaluation research concerning the interventions co-financed from the EU resources in the region: working out and maintenance of comprehensive and cohesive methodologies and structures of evaluation studies, collection of source data, with such data to be used for evaluations (e.g. survey results in the format of non-aggregated databases, non-aggregated indicators etc.).

- Performance of selected evaluations that are especially essential for the regional authorities.

- Collection of data concerning all the interventions performed in the region with the application of EU funds, in the system presented in Table 1, including information on direct effects of the completion of particular projects (e.g. success indicators).

- The Rejected Project Database. 
i) Monitoring of social, economic and spatial transformations in the region, in the context of the regional development OBJECTIVES will allow:

- To prepare regular diagnoses of regional condition allowing for the evaluation of the rate of development objective attainment, including: evaluation of the region's position among Polish and EU regions, identification of problem areas and issues for which interventions would be especially desired, indication of the new possibilities of development and the methods of using such opportunities.

- To draft comprehensive reports on selected issues relating to regional development especially at the given time.

- To prepare projections and options of regional development for the needs of local governments which would allow to connect strongly the decision-making processes with particular research results.

- To prepare and draft materials constituting points of reference for the interrelationship analyses concerning the resources spent and the results received in the region, conducted under Module III.

j) Digital geographical information system processing tools will be applied on a wide scale to the analysis of social, economic and spatial processes in the region. The data will be gathered in reference to address points or under spatial systems.

k) Regional Development Policy Observatories, using solid data that describe the phenomena and social, economic and spatial transformations occurring in the region, as well as holding knowledge on the implemented and completed projects co-financed by the EU, will attempt at interrelating both types of the phenomena under Module III. Such an evaluation will be carried out by analysis and synthesis.

\section{REFERENCES}

Bradley, J., Zaleski, J., Tomaszewski, P., Zębaty, M. and Wojtasiak-Terech, A. (2006), Ocena wplywu Narodowych Strategicznych Ram Odniesienia $i$ wybranych Programów Operacyjnych na lata 2007-2013 na gospodarki polskich województw przy pomocy modeli regionalnych HERMIN, Wrocławska Agencja Rozwoju Regionalnego, Wrocław.

Bukowski, M., Pelle, D. and Saj, W.M. (2008), Wplyw funduszy unijnych na gospodarke Polski w latach 2004-2020, Instytut Badań Strukturalnych, Warszawa.

Kaczor, T., Socha, R. (2008), Badanie wplywu Narodowego Planu Rozwoju 2004-2006 oraz Narodowych Strategicznych Ram Odniesienia 2007-2013 na wybrane wskaźniki dokumentów strategicznych, Warszawa.

Olejniczak, K. (2008), Mechanizmy wykorzystania ewaluacji. Studium ewaluacji średniookresowych INTERREG III, Scholar, Warszawa.

Prawelska-Skrzypek, G. and Romański, B. in: Prawelska-Skrzypek, G., Romański, B., Baran G., Guzik, R., Gwoźdź, K., Jarczewski, W., Kurkiewicz, A., and Micek, G. (2006), Metodologia funkcjonowania Matopolskiego Obserwatorium Polityki Rozwoju, Uniwersytet Jagielloński, Kraków. 
Zaleski, J., Tomaszewski, P., Zębaty, M. and Bradley, J. (2007), Ocena makroekonomicznego wplywu realizacji Narodowego Planu Rozwoju na lata 2004-2006 oraz Narodowych Strategicznych Ram Odniesienia na lata 2007-2013 przy uzyciu modelu HERMIN dla polskiej gospodarki, Wrocławska Agencja Rozwoju Regionalnego, Wrocław.

$<$ www.paiz.gov.pl>

$<$ www.aotm.gov.pl> 